\title{
The roles of plant growth promoting rhizobacteria in sustainable vegetable production in Ethiopia
}

\author{
Habtamu Mekonnen* and Mulugeta Kibret
}

\begin{abstract}
Vegetable production is an important economic activity and a major source of vitamins, minerals, and income in Ethiopia. However, the production of vegetables is much less developed than the production of food grains in the country. Vegetable production still needs improvement in combating biotic and abiotic threats with innovative technologies. Nowadays, excess use of chemical fertilizers to satisfy the increasing demand for food exerts deadly effects on soil microorganisms and contribute to the deterioration of soil fertility and an increase in atmospheric pollution. Several types of research are still going on to understand the diversity and importance of plant growth promoting rhizobacteria (PGPR) and their role in the betterment of vegetable production. PGPR facilitate plant growth directly by either assisting in the acquisition of nutrients (nitrogen, phosphorus, and other essential nutrients) or regulation of the levels of hormones. Indirectly PGPR decrease the inhibitory effects of various pathogens on vegetable growth and development in the forms of biocontrol agents. Some of the notable PGPR capable of facilitating the growth of vegetables such as potato, tomato, pepper, onion belong to genera of Pseudomonas, Bacillus, Azotobacter, Enterobacter, and Azospirillum. Hence, to optimize vegetable production with reduced input of mineral fertilizers and pesticides, the use of PGPR in vegetable cultivation is recommended.
\end{abstract}

Keywords: Biocontrol, Rhizobacteria, Vegetable

\section{Introduction}

Ethiopia is the second most populous country in Africa with a total population of 114,963,588 [1]. This growing population requires a better agricultural production performance than ever before to ensure food security [2]. In Ethiopia, over $85 \%$ of the population depends on agriculture. However, agricultural productivity is low due to lack of advanced agricultural technologies and yield losses caused by biotic and abiotic factors [3].

Growing and using vegetables is an opportunity that has never been adequately prospected to alleviate malnutrition and ameliorate food insecurity in developing countries like Ethiopia [4]. Vegetables are increasingly recognized as essential for food and nutrition security.

\footnotetext{
*Correspondence: habtie2010@gmail.com
}

Department of Biology, Bahir Dar University, Bahir Dar, Ethiopia
They provide an abundant and inexpensive source of energy, body-building nutrients, vitamins, and minerals for good health [5]. In Ethiopia, horticultural crops including fruits, vegetables and root crops contribute to one-fourth of the crop production which is an important economic activity, ranging from smallholder farming to large-scale commercial farms $[3,6]$.

Vegetable production in Ethiopia is not well-developed due to biotic and abiotic threats which reduce vegetable production [3]. Moreover, conventional agricultural practices frequently rely on synthetic fertilizers and pesticides which have adverse effects on humans, animals, and the environment [7]. Considering all the harmful effects of synthetic chemicals, there is an urgent need for developing alternative strategies to solve these problems. In this regard, the use of Plant Growth Promoting Rhizobacteria (PGPR) as vital components of soil fertility, plant growth promotion and antagonistic effects against 
phytopathogens through a wide variety of mechanisms in the rhizosphere is crucial [8].

The rhizosphere is an area around the root surfaces where the biological activity of a microorganism is highest [9]. PGPR are naturally occurring soil bacteria that aggressively colonize plant roots and benefit plants' health [10]. PGPR are involved in all beneficial activities within the soil like decomposition of crop residues, synthesis of soil organic matter, mineralization of soil organic matter, and immobilization of mineral nutrients which help in soil fertility improvement [11].

Several types of research are still going on to understand the diversity and importance of soil PGPR communities and their roles in the betterment of vegetable production. Most potential and widely reported PGPR genera associated with solanaceous vegetable crops include Pseudomonas, Azospirillum, Azotobacter, Klebsiella, Enterobacter, Alcaligenes, Arthrobacter, Burkholderia, Bacillus and Serratia, and endophytic bacteria like Pseudomonas, Bacillus, Xanthomonas, and Erwinia [12]. Besides, rhizospheric bacteria genera like Pseudomonas and Bacillus species were found to be associated with vegetable crops including: tomato, pepper, and potato in Ethiopia [13-16]. Additionally, a few authors also reported that PGPR such as Bacillus cereus BC1AW,
Pseudomonas putida PP3WT and Pseudomonas fluorescens had the ability to produce siderophore HCN, IAA and solubilize phosphate thereby enhancing plant growth and acting as a biological control agent against bacterial wilt disease of tomato and potato $[14,16]$.

Currently, in Ethiopia, well organized and summarized reports concerning PGPR associated with vegetable crops and research status was lacking. Hence, the aim of this review was to summarize the characteristics, mechanism of PGPR and research status associated with vegetable production in Ethiopia.

\section{Mechanism of PGPR}

PGPR are capable of enhancing plant growth either directly or indirectly through multifarious ways (Fig. 1) [17]. Direct mechanisms involve various processes such as phosphate solubilization, nitrogen fixation, production of siderophore, $\mathrm{HCN}$, ammonia, vitamins, and phytohormones (such as auxin, cytokinin, and gibberellins), whereas indirect mechanisms involve that mechanism, which does not directly involve in growth promotion but plays role in the path of synthesis. Indirect mechanisms include ACC deaminase activity, production of antibiotics, hydrolytic enzymes, ISR of phytopathogens $[7,10]$.

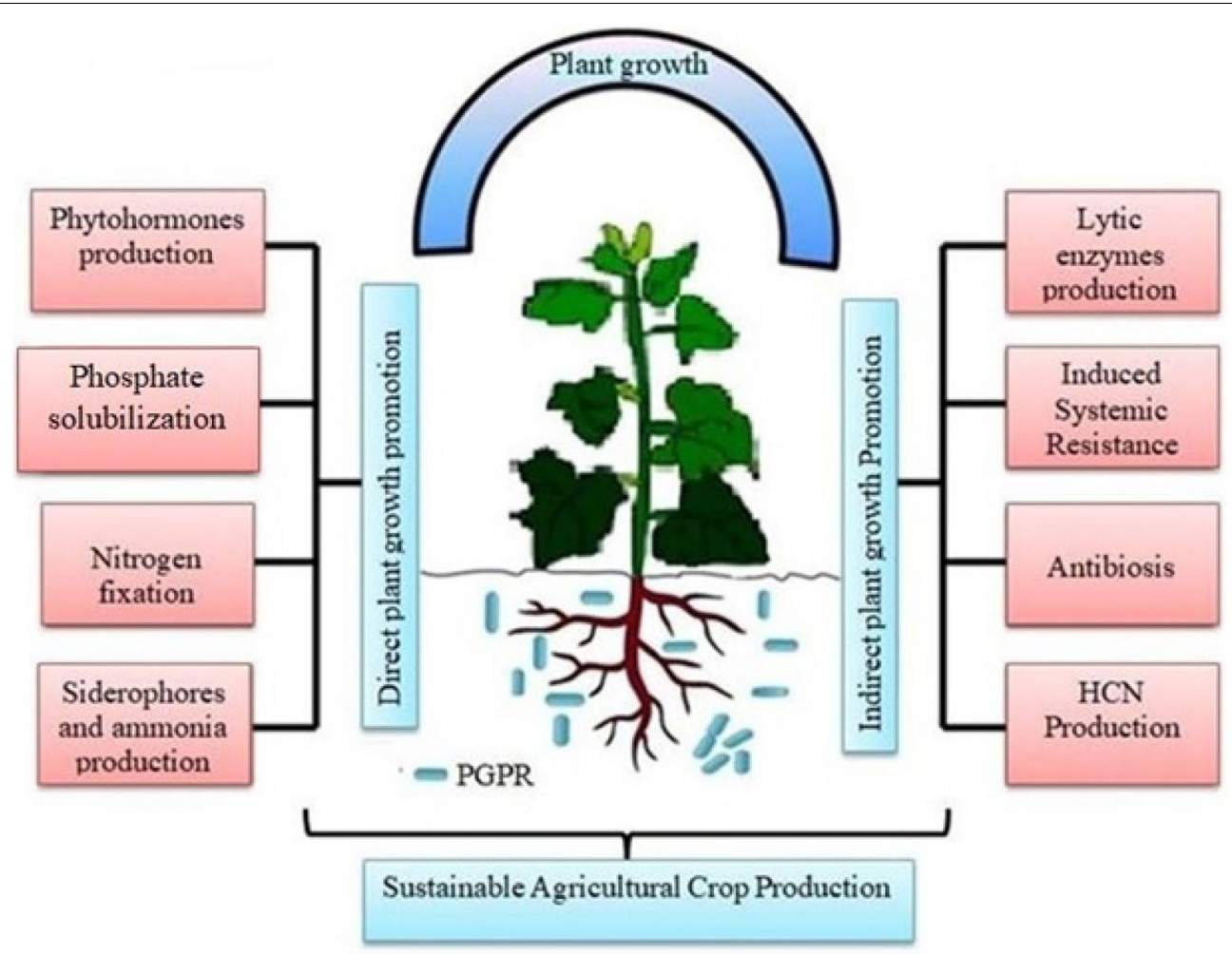

Fig. 1 Schematic representation of showing direct and indirect plant growth promotion [18] 


\section{Phosphate solubilization}

Phosphorus is one of the major and essential macronutrients for the growth and development of plants including tomato. It plays a substantial role in most of the metabolic processes of plants such as photosynthesis, respiration, signal transduction, and energy transfer [17]. However, the maximum amount of phosphorus is found as organic and inorganic insoluble phosphate in the soil. In this regard, phosphate solubilizing bacteria (PSB) play an important role in releasing phosphates from organic molecules or to solubilize insoluble inorganic phosphate. Plants absorb phosphate only as monobasic $\left(\mathrm{HPO}_{4}{ }^{-}\right)$and the dibasic $\left(\mathrm{H}_{2} \mathrm{PO}_{4}{ }^{2-}\right)$ ions [19].

The mechanism of phosphate solubilization by PSB is associated with the release of low molecular weight organic acids (acetate acid, lactic acid, oxalic acid, tartaric acid, succinic acid, citric acid, gluconic acid, ketogluconate, and glycolic) through which their hydroxyl and carboxyl groups chelate the cations bound to the phosphate, ultimately converting it into soluble forms [20]. Phosphates are released from organic molecules by different mechanisms. Phosphatases dephosphorylate the phospho-ester bonds; phytases, act by releasing phytic acid; phosphonatases catalyze the hydrolysis of phosphonoacetaldehyde to acetaldehyde and phosphate using $\mathrm{Mg}(\mathrm{II})$ as cofactor and C-P lyases perform C-P cleavage of phosphonates [21, 22]. Phosphate solubilizers such as Acidovorans delafieldii, Azotobacter chroococcum, Bacillus megaterium, Bacillus anthina, Enterobacter cloacae, P. putida, P. fluorescens, Pseudomonas agglomerans, Pseudomonas cepacia, Microbacterium laevaniformans, Xanthomonas maltophilia, and Rhizobium species on some of the widely grown and consumed vegetables like tomato, potato, pepper, cucumber has been reported [17, 23].

\section{Nitrogen fixation}

More than $80 \%$ of nitrogen is present in the atmosphere as inert gas which is insoluble to the plants [20]. Nitrogen fertilizer is applied to supply nitrogen for the growth and productivity of the plants. However, less than half of applied nitrogen is effectively absorbed by plants with the rest being lost through volatilization or leaching subsequent polluting the environment [7]. Nitrogen is converted into ammonia (plant utilizable forms) by nitrogen-fixing organisms using a complex enzyme system called nitrogenase [24].

Biological nitrogen fixation is a process that accounts for almost two-thirds of nitrogen fixed worldwide which is carried out either symbiotic or free-living between microbes and plants [19]. Symbiotic nitrogen fixation carried out between legume and symbiotic microorganisms such as Rhizobium, Mesorhizobium, Azorhizobium, Bradyrhizobium, Azorhizobium, Allorhizobium, and Sinorhizobium which has been described as nitrogen-fixing PGPR with significant ability to promote plant growth and yield $[25,26]$. Whereas, free-living nitrogen-fixing PGPR include Azotobacter, Azospirillum, Herbaspirillum, Bacillus, Burkholderia, and Paenibacillus, which have been shown to attach to the root and efficiently colonize root surfaces [17].

\section{Phytohormones production}

Phytohormones are naturally occurring organic compounds that influence various physiological or morphological processes in plants, such as cell elongation and cell division at extremely low concentrations [10]. These phytohormones conspicuously affect the metabolic activity of plants and also indirectly contributed to the stimulation of defense as well as abiotic stress management such as drought, salinity, heat, cold, flooding, and ultraviolet radiation are the severe problem resulting in huge loss of crops production worldwide. In this regard, PGPR secretes various phytohormones includes auxin, cytokinin, ethylene, gibberellins (GA), and abscisic acid (ABA) $[27,28]$.

Indole-3-acetic acid (IAA), one of the most physiologically active auxins, is produced by $80 \%$ of PGPR which promote several growth and developmental events, such as cell division, elongation, and differentiation [17]. Acinetobacter, Pseudomonas, Rhizobium, Azospirillum, Bacillus and Klebsiella are the most common genera of bacteria involved in the biosynthesis of IAA in the rhizosphere of different crops [9]. Among these bacterial genera, Pseudomonas spp. are the most powerful producer of IAA, whereas Pseudomonas putida produces more IAA than Pseudomonas fluorescens in production of IAA [28].

Gibberellin has a vital role in seed germination and emergence, floral induction, flower and fruit development, and steam and leaf growth whereas the most dominant physiological effect of GA is shoot elongation [27]. Gibberellin is naturally produced by higher plants, fungi and bacteria [20]. A variety of PGPR producing GA include Acetobacter diazotrophicus, Azospirillum lipoferum, Bacillus pumilus, Bacillus cereus, Bacillus macrolides and Herbaspirillum seropedicae, Acinetobacter calcoaceticus [25].

Ethylene is a key phytohormone having a vast range of biological functions including plant growth and development. It promotes root initiation, inhibits root elongation, reduces wilting, enhances fruit ripening, stimulates seed germination, and activates the production of other plant hormones [17]. The presence of 1-aminocyclopropane-1-carboxylate (ACC) deaminase producing PGPR plays an active role in the modulation of ethylene levels 
in the plants [28]. Bacterial synthesizing ACC deaminase belongs to genera the Pseudomonas, Bacillus, Acinetobacter, Azospirillum, Achromobacter, Enterobacter, Burkholderia, Agrobacterium, Alcaligenes, Rhizobium, and Serratia [17].

Cytokinins are a class of phytohormones that are known to promote cell divisions, cell enlargement and tissue expansion in certain plant parts [29]. Plant responses to exogenous applications of cytokinins promote seed germination, the release of buds from apical dominance, stimulation of leaf expansion and reproductive development, retardation of senescence, enhanced cell division, enhanced root development, inhibition of root elongation, shoot initiation, or certain other physiological responses [20]. The role of cytokinins producing bacterial genera including Pseudomonas, Klebsiella, Enterobacter, Achromobacter, Bacillus, Paenibacillus, Azotobacter, Agrobacterium, Azospirillum, Flavobacterium, and Arthrobacter in plant growth regulation [25, 30, 31].

\section{Hydrogen cyanide production}

The production of $\mathrm{HCN}$ is vital to plant growth promoting activity of plant growth promoting strains. Hydrogen cyanide frequently used as a biocontrol agent in the agricultural production system on the basis of significant toxicity against plant pathogens, chelating of metals ions and also indirectly involved in making phosphate available [32]. A number of scholars reported that HCN-producing PGPR and their use as a biofertilizer in growth promotion, yield enhancement and also control of tomato disease [17]. Many bacterial genera such as Aeromonas, Pseudomonas, Bacillus, and Enterobacter isolated from tomato rhizosphere have been found to release $\mathrm{HCN}$ [25].

\section{Siderophore production}

Microbes have difficulty in obtaining sufficient iron to support their growth in the rhizosphere because of ferric oxide formation as a result of the conversion of the surface iron into insoluble form like oxyhydroxide under aerobic conditions. Iron is required as an enzyme cofactor, oxygen metabolism, electron transfer, and DNA and RNA syntheses and also essential for biofilm formation $[12,20]$. Siderophores produced by PGPR support the fulfillment of required iron for plants by making it soluble and chelating from available complex organic or inorganic iron [33].

Some microorganisms produce siderophore that chelates the available iron and competitively prevents the iron nutrition of phytopathogen [34]. Siderophore is produced by Alcaligenes, Pseudomonas, Bradyrhizobium, Bacillus, Enterobacter and Rhizobium [24]. Siderophore production confers competitive advantages to PGPR that can colonize roots and exclude other microorganisms from this ecological niche. Under highly competitive conditions, the ability to acquire iron via siderophores may determine the outcome of competition for different carbon sources that are available as a result of root exudation or rhizo-deposition [35].

\section{Induced systemic resistance}

PGPR systemically activate the plant's latent defense mechanism and hence, improve plant resistance against pathogens called induced systemic resistance (ISR) [36, 37]. There are many reports where PGPR have been found to induce plant defense by inhibiting the pathogens. For instance, Bacillus amyloliquefaciens, Lactobacillus paracasei, P. fluorescens, and P. putida induce IRS against phytopathogens of tomato [31,38-40].

\section{Antibiotics}

Many of the PGPR strains produce antibiotics that are inhibitory to plant pathogens and suppress their growth [17]. Various interactions shown between multiple groups of soil organisms are common, such as predation and competition for resources [37]. Numerous PGPR, such as Bacillus subtilis, Bacillus amyloliquefaciens, Bacillus velezensi, P. putida, P. fluorescens, Pseudomonas brassicacearum, and Paenibacillus polymyxa produce different antibiotics, such as surfactin, bacillomycin, fengycin, iturin, 2,4-diacetylphloroglucinol, polymyxin and fusaricidin, which strongly inhibit the growth of Ralstonia solanacearum $[41,42]$.

\section{PGPR in vegetable production}

\section{PGPR for enhanced growth, yields and fruit quality}

PGPR involved in all beneficial activities within the soil like decomposition of crop residues, synthesis of soil organic matter, mineralization of soil organic matter, immobilization of mineral nutrients, phosphate solubilization, nitrification and phytohormone synthesis which help in soil fertility improvement and eventually improving the productivity (Fig. 2) [11]. Rhizobacteria associated with roots are responsible for the synthesis of a large number of biomolecules which get mixed with the soil and further improve soil health. They also act on the plant residues, where various organic compounds undergo decomposition and mineralization [43]. Various volatile compounds and other metabolites (enzymes, proteins, antibiotics, etc.) also produced by PGPR are highly involved in improving soil health and plant growth promotion. Many bacterial species from different genera including Bacillus, Pseudomonas, Serratia, Arthrobacter, and Stenotrophomonas have been reported as volatile compound producers [44]. 


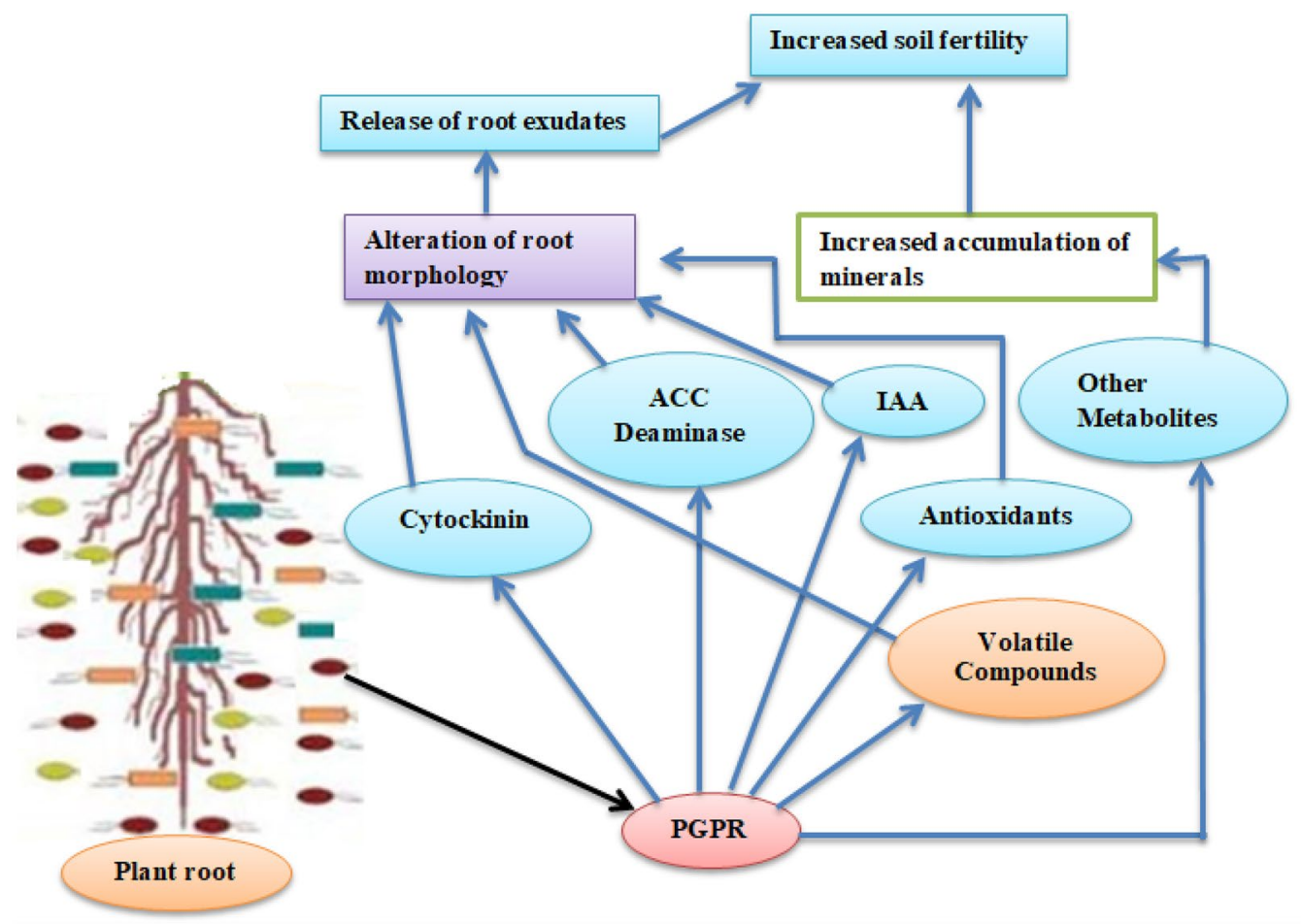

Fig. 2 PGPR has potential role in developing sustainable systems in crop production [11]

A better understanding of the plant growth-promotion activity of PGPR is likely to enhance the production of safe, fresh, and high-quality tomatoes while reducing chemical inputs in different agronomic setups [17]. In Ethiopia, a study on Pseudomonas isolates on growth of tomato plants reported that a significant difference in the root length, shoot length and shoot dry weight of tomato plants was observed under greenhouse condition [45]. In addition, the highest dry and fresh weight tomato was recorded with Pseudomonad APF1 and B. subtilis B2G treatments [13] Moreover, Kurabachew and Wydra [14] reported that rhizobacterial isolates $B$. cereus $\mathrm{BC} 1 \mathrm{AW}$ and $P$. putida PP3WT from tomato plant increased shoot dry weight by $75 \%, 62.5 \%$ in genotype KK 2 and by $57.1 \%$, $50 \%$ in genotype L390, respectively, in pot experiments.

Plant growth promoting rhizobacteria are being tried as consortia and have been found to be more effective than single inoculation [12]. According to Messele et al. [15] the growth parameters of pepper plants significantly increased in the dual inoculation of Bacillus and Trichoderma spp. to local pepper varieties (marko fana, and oda haro), ranging from the height of $(37-45.33 \mathrm{~cm})$ and dry weight of (16.5-40 g/12 plants) compared to the individual one (26.3-33.33 cm and 17.4-30.5 g/12 plants). Moreover, the dual inoculation with Trichoderma spp. and Bacillus spp. gave the highest records of growth parameters, fruit yields and plant nutrient content than individual one, in pot experiments [46].

\section{Systemic tolerance and systemic resistance induction in vegetables}

Biocontrol is an emerging trend by increasing plant fitness, productivity, and resistance to diseases in sustainable agriculture [47]. Apart from abiotic factors that hit vegetable production around the world, loss due to phytopathogens is equally substantial in many countries. For instance, high loss $(40 \%)$ was observed in potato due to pathogen disease $[48,49]$.

PGPR induce physical and chemical changes in plants and, hence improve plant resistance, which is designated by induced systemic resistance (ISR) [50]. The application of different PGPR strains to the seeds or seedlings of certain plants has resulted in increased efficiency of ISR against several pathogens. Various nonpathogenic PGPR strains can induce systemic disease resistance in plants against broad-spectrum phytopathogens [51].

Elicitation of the plant's defense by PGPR has received increasing attention in recent years [52]. PGPR genera such as Pseudomonas, Alcaligenes, Paenibacillus, and Chryseobacterium have been reported as systemic resistance inducers in potato, tomato, and Chinese cabbage against pathogens like Bemisia tabaci, Fusarium, 
Macrophomina phaseolina, Rhizoctonia solani, Ralstonia solanacearum, Colletotrichum orbiculare, Botrytis cinerea, and Pectobacterium carotovorum [36, 53]. Rai and Nabti [23] reported that inoculation of field soil in pots with Pseudomonas protegens RS-9 led to significant increase in plant height and dry weight of tomato plant, incidence of bacterial wilt reduced by $65.6 \%$ and reduce the pathogen by $63 \%$ in the soil as compared to the pathogen inoculated only control. The study revealed that Pseudomonas protegens RS-9 is a promising strain for biocontrol of bacterial wilt of tomato.

Consortium treatment of Bacillus thuringiensis and Trichoderma viride showed high early blight disease suppression (30.76\%, disease incidence) and a high yield of potato $\left(2.78 \mathrm{t} / \mathrm{ha}^{-1}\right)$. Besides, a combination of T. viride and $P$. fluorescens reduced early blight disease incidence by $31.67 \%$ and increased the yield of potato by $2.39 \mathrm{t} / \mathrm{ha}^{-1}$ compared to the control under field condition. This study reported that seed treatment with a combination of $T$. viride and $P$. fluorescens and also between $T$. viride and $B$. thuringiensis can become part of integrated management of early blight disease of potato and plant growth promotion [54]. In Ethiopia, Kurabachew and Wydra [14] evaluate the potential PGPR for their ability to suppress the growth of $R$. solanacearum both under in vitro and in vivo conditions in tomato genotypes. Isolates of B. cereus BC1AW and P. putida PP3WT significantly reduced bacterial wilt incidence in tomato genotypes King Kong 2 (moderately resistant) in the pot experiments by $46.8 \%$ and $44.7 \%$ and in L390 (susceptible) by $33.6 \%$ and $30 \%$, respectively, in pot experiments. While in split root experiments they reduced wilt incidence by 48.7\%, 43.2\% and 25.7\% and 20.1\% in King Kong 2 and L390, respectively. Shoot dry weight also increased in plants treated with BC1AW and PP3WT and reduced the number of $R$. solanacearum cells by in mid-stems of both tomato genotypes. Hence, ISR is only one of the mechanisms that may be mobilized to counteract plant pathogens in an environmentally friendly and durable way. Integrating ISR triggering PGPR into disease management programs in conjunction with other strategies will be a worthwhile approach to explore [55].

PGPR induce physiological and chemical changes in plants that result also in enhanced tolerance to environmental stresses (drought, salinity, heavy metals, high temperature) which is known as induced systemic tolerance (IST) [56]. This abiotic stress has a high negative impact on survival, biomass production and production of staple food crops up to $70 \%$, which threatens food security worldwide. Aridity stress imparted by drought, salinity, and high temperature is the most dominant abiotic stress limiting plant growth and productivity [44]. Among the options used to alleviate the degree of cellular damage caused by water stress include the exogenous application of PGPR in compatible osmolytes, such as proline, glycinebetaine, and trehalose which has gained considerable attention for mitigating the effect of stress [19].

The use of PGPR in plant abiotic stress management has been widely studied. Habib et al. [57] reported that an enhanced salinity stress tolerance in okra through Reactive Oxygen Species (ROS) scavenging enzymes and an improved water use efficiency, which is initiated by PGPR. The other studies have also reported that Bacillus, Pseudomonas, Achromobacter, Variovorax, Citrobacter and Mesorhizobium could be used to improve potato and tomato growth under drought stress [58, 59]. In Ethiopia, much research has not been done.

\section{PGPR hydrolytic enzymes}

Bacterial lytic enzymes such as urease, esterase, lipase, protease, chitinase, amylase, and cellulase are key protagonists in the biological transformation processes of $\mathrm{N}$, $\mathrm{H}$, and $\mathrm{C}[23,60]$. Hydrolytic enzymes are involved in the lysis of the fungal cell wall. These enzymes deform components of cell wall of fungal pathogens. It is one of the important mechanisms for the eco-friendly control of soil-borne pathogens [61]. Numerous microbial strains like Serratia marcescens, Bacillus cereus, Bacillus thuringiensis and many more have a potential to produce hydrolytic enzymes for the biocontrol of phytopathogens like Rhizoctonia solani, Fusarium oxysporum, Sclerotium rolfsii, Pythium ultimum by swelling in the hyphae and at the hyphal tip, hyphal curling or bursting of the hyphal tip of the fungal pathogens [62].

The application of such bacteria for biological protection of crops from pathogens that contain chitin and glucans within their cell wall structure is widely assumed [23]. The role of chitinolytic Streptomyces vinaceusdrappus S5MW2 in enhancing tomato plant growth and biocontrol efficacy through chitin supplementation against $R$. solani was reported. Under the greenhouse experiment, chitin supplementation with S5MW2 showed that colloidal chitin (CC) supplementation with S5MW2 showed significant growth of tomato plants and superior disease reduction as compared to untreated control and without CC treated plants. Moreover, a high accumulation of chitinase also recovered in the CC supplemented plants [63].

Bacillus spp. attach to the mycelial cell walls, and the chitosanase, protease, cellulase, glucanase, siderophores, and HCN of the bacteria crack and deform the hyphae, which leads to altered cell structure and functions due to vacuolation and protoplast leakage [64]. Moreover, another recent study on Paenibacillus polymyxa strain SC09-21 as a biocontrol agent of Phytophthora blight and growth stimulation in pepper plants showed that strain 
SC09-21 significantly reduced Phytophthora blight severity and increased phenylalanine ammonia-lyase, peroxidase, polyphenol oxidase, and superoxide dismutase activities. Besides, SC09-21 boosted pathogenesis related protein gene expression in pepper plants [65].

PGPR against fungal and bacterial pathogens of vegetable Biological control of crop diseases is receiving increased attention as an environmentally sound alternative to chemical pesticides [66]. The use of rhizosphere resident microbial antagonists specifically the fluorescent Pseudomonas is noted as a promising control method. Among the rhizosphere organisms, fluorescent Pseudomonas strains are often selected for biological control strategies because of their ability to utilize varied substrates under different conditions, short generation time and motility that assist colonization of roots [29] and also produce siderophores responsible for the biological suppression of several soil-borne plant pathogens [67]. Moreover, many rhizospheric isolates belonging to Bacillus spp., Enterobacter spp., Pseudomonas spp., Pichia spp. collected from tomato and pepper growing areas showed antagonistic activity against Botrytis cinerea, Fusarium graminearum, Colletotrichum capsici, Alternaria solani, Phytophthora capsici and Mycosphaerella melonis investigated effects of rhizobacteria on the early growth of cucumber and tomato seedlings and reported that Azospirillum spp., Pseudomonas spp. inhibited the growth of Fusarium spp.,
Pythium spp. and Rhizoctonia spp. on both plants [12, 68].

There are few reports of PGPR in Ethiopia as biological control agents against bacterial wilt disease. Kuarabachew et al. [16] stated that $P$. fluorescens significantly reduced the incidence of potato bacterial wilt and increased plant growth under greenhouse experiments. With a similar study carried out by Lemessa and Zeller [13] on the screening of rhizobacteria for in vitro and plants antagonistic activity against $R$. solanacearum for biological control in Ethiopia, it was found that the most effective strains (P. fluorescent APF1 and B. subtilis B2G) consistently reduced wilt diseases of tomato and increased plant weight significantly. The Pseudomonas APF1 strain showed the greatest plant growth promotion effect, increasing plant dry weight to $63 \%$ (Table 1). Besides, Kinyua et al. [69] and Guchi [67] various integrated management options for controlling bacterial wilt have been developed in Ethiopia, Kenya, and Uganda and are currently being disseminated on-farm in several other PRAPACE member countries.

Bacteria belonging to the genera of Pseudomonas, Bacillus, and Trichoderma the fungi are the most promising biocontrol agents against a range of plant pathogens under a variety of environmental conditions [66]. According to Messele et al. [15], dual culture technique on Colletotrichum isolates from pepper showed that isolates of Bacillus and Trichoderma in combination showed the greatest pepper anthracnose disease reduction of

Table 1 Plant growth promoting rhizobacteria used as biofertilizer and biocontrol agent

\begin{tabular}{|c|c|c|c|c|}
\hline PGPR & Host plant & Pathogen/pest & PGPR traits & References \\
\hline Pseudomonas isolates & Solanum lycopersicum & Not tested & $\begin{array}{l}\text { Phosphate solubilization, } \\
\text { improved tomato growth }\end{array}$ & Fenta and Assefa [45] \\
\hline $\begin{array}{l}\text { Bacillus cereus BC1AW and Pseu- } \\
\text { domonas. putida PP3WT }\end{array}$ & Solanum lycopersicum & Ralstonia solanacearum & $\begin{array}{l}\text { Phosphate solubilization, pro- } \\
\text { duction of siderophore, HCN } \\
\text { and IAA, reduce bacterial wilt } \\
\text { incidence, increased dry weight } \\
\text { of tomato }\end{array}$ & Kurabachew and Wydra [14] \\
\hline Pseudomonas fluorescens & Solanum tuberosum & Ralstonia solanacearum & $\begin{array}{l}\text { Production of siderophore, } \\
\text { reduced bacterial wilt incidence } \\
\text { and improve potato growth }\end{array}$ & Kuarabachew et al. [16] \\
\hline $\begin{array}{l}\text { Pseudomonas fluorescent APF1 and } \\
\text { Bacillus subtilis B2G }\end{array}$ & Solanum lycopersicum & Ralstonia solanacearum & Increased fresh and dry weight & Lemessa and Zeller [13] \\
\hline Bacillus and Trichoderma isolates & Capsicum annuum & Colletotrichum capsici & $\begin{array}{l}\text { Reduce pepper anthracnose } \\
\text { disease }\end{array}$ & Messele et al. [15] \\
\hline $\begin{array}{l}\text { Trichoderma viride-ES1 and Pseu- } \\
\text { domonas fluorescens-Bak150 }\end{array}$ & Solanum tuberosum & Phytophthora infestans & $\begin{array}{l}\text { Suppression of early blight disease } \\
\text { and increased yield of potato }\end{array}$ & Zegeye et al. [70] \\
\hline Bacillus thuringiensis & Solanum lycopersicum & Tuta absoluta & $\begin{array}{l}\text { Decreased in egg hatching and } \\
\text { adult emergence }\end{array}$ & Youssef and Hassan [71] \\
\hline Bacillus firmus & Solanum lycopersicum & Meloidogyne incognita & $\begin{array}{l}\text { Reduced nematode populations, } \\
\text { gall formation and number } \\
\text { of eggs, increased biomass of } \\
\text { tomato }\end{array}$ & Terefe et al. [72] \\
\hline
\end{tabular}


(91- 97\%) when compared to pathogen-inoculated (control) plants. Moreover, the biocontrol potential of Trichoderma viride-ES1 and $P$. fluorescens-Bak150 against potato late blight pathogen (Phytophthora infestans) under greenhouse conditions, the results showed that $T$. viride and $P$. fluorescens significantly reduced the disease compared to the untreated controls. The foliar application of T. viride-ES1 has good potential in controlling the late blight disease of potato [70] (Table 1).

\section{PGPR against nematode and insect pests}

The manipulation of beneficial organisms remains a very important tool in an integrated pest management program of insect pests worldwide [73]. There are many diverse kinds of bacteria that are identified to acutely or chronically infect insects, but only two genera have ever been registered to control insects, i.e., Bacillus and Serratia. Bacillus is by far the most significant microbial pesticide genus. B. thuringiensis has been the most widely used and successful microbial pesticide [73] and also fluorescent pseudomonads are shown to be effective against certain insects and nematodes [74].

Youssef and Hassan [71] reported that some isolates of $B$. thuringiensis and the most commonly used $B$. thuringiensis based formulates to control Tuta absoluta under laboratory conditions showed high mortality of $4^{\text {th }}$ instar larvae and a significant decrease in egg hatching compared to the control. Another study in Iran showed that bacterial isolates and protein crystals produced by $B$. thuringiensis during the sporulation are toxic to different larval instars of $T$. absoluta and resulted in rapid death of the target pests [75]. Similarly, the combined application of spinosad and B. thuringiensis appears to be a promising biocontrol agent against tomato leaf miner under greenhouse conditions [76]. Furthermore, the entomopathogenic fungi, Beauveria bassiana and Metarhizium anisopliae are reported as promising agents against T. absoluta under greenhouse conditions [77].

The most important PGPR fluorescent pseudomonads promote plant growth, increase rhizosphere colonization and suppressed nematodes [78]. According to Al-Shalaby and Sedik [79] bacterial isolates of Mycobacterium spp., Micrococcus spp., Escherichia coli, Bacillus subtilis, Serratia marcescens, Pseudomonas aeruginosa and Sarcina spp. significantly reduced numbers of galls, their developmental stages, and egg masses in roots due to root-knot nematode (Meloidogyne incognita) infecting eggplant, under greenhouse conditions.

According to the reports of Cetintas et al. [80], $B$. pumilus strain decreased plant root galling and increased plant height, shoot fresh and dry weight, and root fresh weight. Isolates ZHA296 and ZHA178 of Paenibacillus castaneae reduced the number of egg masses and root galling with no effects on plant growth compared to the control. While the isolate ZHA17 of Mycobacterium immunogenum increased plant height and shoot fresh weight. Results indicated that among the tested bacterial strains, ZHA296 and ZHA178 of P. castaneae and ZHA17 and ZHA57 of M. immunogenum were identified as the promising biocontrol agents for future nematode management tactics. In Ethiopia, Bacillus firmus, commercial WP formulation (BioNem) was evaluated against the root-knot nematode $M$. incognita. In the greenhouse trial, BioNem applied at $8 \mathrm{~g} /$ pot planted with a tomato seedling reduced gall formation by $91 \%$, final nematode populations by $76 \%$ and the number of eggs by $45 \%$. Consequently, plant height and biomass were increased by $71 \%$ and $50 \%$, respectively, compared to the untreated control. In the field trials, BioNem applied at 200 and $400 \mathrm{~kg} \mathrm{ha}^{-1}$ was effective in reducing the number of galls (75-84\%) and increased shoot height (29-31\%) and weight $(20-24 \%)$ over the untreated control. This study revealed that $B$. firmus is a promising microorganism for the biocontrol of $M$. incognita in tomato pots [72].

\section{Conclusion}

Ethiopia has a comparative advantage in several vegetable crops due to its favorable climate. Like many other crops, vegetables are threatened by biotic and abiotic stresses. Thus, scientists and vegetable growers are working hard to develop different strategies to overcome these problems. Among the options, the use of PGPR in agricultural practices has received greater attention. PGPR play significant role in the soil which proves beneficial for vegetable health and productivity. PGPR benefit plant growth and development through various direct and indirect mechanisms like the production of secondary metabolites, i.e., plant growth substances, phosphate solubilization, siderophores production, as biocontrol of fungal and bacterial pathogens, insect pests and nematodes, and promote induced systemic resistance. Various species of rhizospheric bacteria like $P$. fluorescent, $P$. putida, $B$. subtilis, $B$. firmus, $B$. cereus and $B$. thuringiensis associated with vegetable crops including tomato, pepper, and potato in Ethiopia. These groups of PGPR play substantial role in vegetable growth, biocontrol of nematode $(M$. incognita), Phytophthora blight caused by $P$. infestans and bacterial wilt caused by $R$. solanacearum. Studies of PGPR in the Ethiopian context assessed only the mechanism of PGPR against bacterial pathogens, but the mechanisms of PGPR against fungal pathogens, nematode, and insect pests were not addressed. Moreover, the effectiveness of the potential isolates was not tested under field conditions. Extensive studies should be done on the mechanisms of PGPR and also potential PGPR should be tested under field conditions so that potential vegetable 
specific PGPR inoculants can be developed for practical application on sustainable vegetable production in Ethiopia and these may provide the farmers with methods of enhancing their productivity with environmentally friendly technologies. Therefore, considerable attention should be taken by scientists and vegetable growers to use PGPR for enhancing vegetable production in different agro-ecological areas.

\author{
Abbreviations \\ ACC: 1-Aminocyclopropane-1-carboxylate; CC: Colloidal Chitin; HCN: Hydro- \\ gen Cyanide; IAA: Indole-3-Acetic Acid; ISR: Induced Systemic Resistance; \\ PGPR: Plant Growth Promoting Rhizobacteria; PSB: Phosphate Solubilizing \\ Bacteria; ROS: Reactive Oxygen Species.
}

\section{Acknowledgements}

Not applicable.

\section{Authors' contributions}

HM and MK wrote the manuscript. Both authors read and approved the final manuscript.

\section{Funding}

The authors received no specific funding for this work.

\section{Availability of data and materials}

Not applicable because it is review work.

\section{Ethics approval and consent to participate}

Not applicable.

\section{Consent for publication}

Not applicable.

\section{Competing interests}

The authors declare that they have no competing interests.

Received: 21 September 2020 Accepted: 23 January 2021

Published online: 24 February 2021

\section{References}

1. Worldometer. Countries in the world by population. www. Worldomete rs.Info/world-population/population-by-country. 2020.

2. Amelework K, Assefa A. Assessment of farmers perception on the status, classification and management practices of soil fertility in comparison to scientific practices: In the case of Ada'a district, central highlands of Ethiopia. Ethiopia: Addis Ababa University; 2017.

3. Welderufael AH. Assessment of horticultural crops (vegetables, tubers and fruits) production constraints and opportunities in west and southwest shewa zones of oromia region Ethiopia. Int J Agri Econ. 2016;1(3):84-90.

4. Hunde NF. Opportunity, problems and production status of vegetables in Ethiopia: a review. J Plant Sci Res. 2017;4(2):1-13.

5. Schreinemachers P, Simmons EB, Wopereis MC. Tapping the economic and nutritional power of vegetables. Glob Food Sec. 2018;16:36-45.

6. Central Statistical Agency. Agricultural sample survey. Report on area and production of major crops. Www.Csa.Gov.Et. 2015.

7. Aloo BN, Makumba BA, Mbega ER. The potential of bacilli rhizobacteria for sustainable crop production and environmental sustainability. Microbiol Res. 2019;219:26-39.

8. Méndez-Bravo A, Cortazar-Murillo EM, Guevara-Avendaño E, CeballosLuna O, Rodríguez-Haas B, Kiel-Martínez AL, et al. Plant growth-promoting rhizobacteria associated with avocado display antagonistic activity against Phytophthora cinnamomi through volatile emissions. PLOS ONE. 2018;13(3):1-13.
9. Choudhary M, Ghasal PC, Yadav RP, Meena VS, Mondal T, Bisht J. Towards plant-beneficiary rhizobacteria and agricultural sustainability. Role of rhizospheric microbes in soil: Springer; 2018. p. 1-46.

10. Parewa HP, Meena VS, Jain LK, Choudhary A. Sustainable crop production and soil health management through plant growth-promoting rhizobacteria. Role of rhizospheric microbes in soil: Springer; 2018. p. 299-329.

11. Sharma IP, Chandra S, Kumar N, Chandra D. PGPR: Heart of soil and their role in soil fertility. Agriculturally important microbes for sustainable agriculture: Springer; 2017. p. 51-67.

12. Gupta S, Kaushal R. Plant growth promoting rhizobacteria: Bioresource for enhanced productivity of solanaceous vegetable crops. Acta Sci Agri. 2017;1(3):10-5.

13. Lemessa F, Zeller W. Screening rhizobacteria for biological control of Ralstonia solanacearum in Ethiopia. Biol Cont. 2007:42(3):336-44.

14. Kurabachew H, Wydra K. Characterization of plant growth promoting rhizobacteria and their potential as bioprotectant against tomato bacterial wilt caused by Ralstonia solanacearum. Biol Cont. 2013;67(1):75-83.

15. Messele A, Serawit H, Tesfaye A. In vitro and in vivo evaluation of antagonistic microbes against pepper anthracnose (Colletotrichum capsici (syd.) bisby and butler. Int J Environ Sci. 2017;6(3):87-93.

16. Kuarabachew $H$, Assefa F, Hiskias Y. Evaluation of Ethiopian isolates of Pseudomonas fluorescens as biocontrol agent against potato bacterial wilt caused by Ralstonia (Pseudomonas) solanacearum. Acta Agri Solvenica. 2007;90(2):125-35.

17. Ahmed B, Zaidi A, Khan MS, Rizvi A, Saif S, Shahid M. Perspectives of plant growth promoting rhizobacteria in growth enhancement and sustainable production of tomato. Microbial strategies for vegetable production: Springer; 2017. p. 125-49.

18. Mhatre PH, Karthik C, Kadirvelu K, Divya K, Venkatasalam E, Srinivasan $\mathrm{S}$, et al. Plant growth promoting rhizobacteria (PGPR): A potential alternative tool for nematodes bio-control. Biocatal Agri Biotechnol. 2019;17:119-28.

19. Gouda S, Kerry RG, Das G, Paramithiotis S, Shin H-S, Patra JK. Revitalization of plant growth promoting rhizobacteria for sustainable development in agriculture. Microbiol Res. 2018;206:131-40.

20. Patel S, Minocheherhomji FP. Plant growth promoting rhizobacteria: Blessing to agriculture. Int J Pure Appl Biosci. 2018;6:481-92.

21. Selvakumar G, Bindu GH, Bhatt RM, Upreti KK, Paul AM, Asha A, et al. Osmotolerant cytokinin producing microbes enhance tomato growth in deficit irrigation conditions. Biol Sci. 2016;1:1-7.

22. Morais MC, Zhang W, Baker AS, Zhang G, Dunaway-Mariano D, Allen KN. The crystal structure of Bacillus cereus phosphonoacetaldehyde hydrolase: Insight into catalysis of phosphorus bond cleavage and catalytic diversification within the HAD enzyme superfamily. Biochem. 2000;39(34):10385-96.

23. Rai A, Nabti E. Plant growth-promoting bacteria: Importance in vegetable production. Microbial strategies for vegetable production: Springer; 2017. p. 23-48.

24. Shaikh S, Sayyed R. Role of plant growth-promoting rhizobacteria and their formulation in biocontrol of plant diseases. Plant microbes symbiosis: Applied facets: Springer; 2015. p. 337-51.

25. Vaikuntapu PR, Dutta S, Samudrala RB, Rao VR, Kalam S, Podile AR. Preferential promotion of tomato (Lycopersicon esculentum) growth by plant growth promoting bacteria associated with tomato. Indian J Microbiol. 2014;54(4):403-12.

26. Hayat R, Ali S, Amara U, Khalid R, Ahmed I. Soil beneficial bacteria and their role in plant growth promotion: a review. Ann microbiol. 2010;60(4):579-98.

27. Egamberdieva D, Wirth SJ, Alqarawi AA, Allah EF, Hashem A. Phytohormones and beneficial microbes: essential components for plants to balance stress and fitness. Front Microbiol. 2017:8:1-14.

28. Singh M, Singh D, Gupta A, Pandey KD, Singh P, Kumar A. Plant growth promoting rhizobacteria: Application in biofertilizers and biocontrol of phytopathogens. PGPR amelioration in sustainable agriculture: Elsevier; 2019. p. 41-66.

29. Nasir S. Review on major potato disease and their management in Ethiopia. Int J Horti Flori. 2016;4(5):239-46.

30. Premachandra D, Hudek L, Brau L. Bacterial modes of action for enhancing of plant growth. J Biotechnol Biomat. 2016;6(3):1-8. 
31. Boukerma L, Benchabane M, Charif A, Khelifi L. Activity of plant growth promoting rhizobacteria (PGPRs) in the biocontrol of tomato fusarium wilt. Plant Prot Sci. 2017;53(2):78-84.

32. Rijavec T, Lapanje A. Hydrogen cyanide in the rhizosphere: Not suppressing plant pathogens, but rather regulating availability of phosphate. Fronti Microbiol. 2016;7:1-14.

33. Singh R, Pandey D, Kumar A, Singh M. PGPR isolates from the rhizosphere of vegetable crop Momordica charantia: Characterization and application as biofertilizer. Int J Curr Microbiol Appl Sci. 2017;6(3):1789-802.

34. Shaikh SS, Sayyed RZ. Reddy MS. Plant growth-promoting rhizobacteria: An eco-friendly approach for sustainable agroecosystem. Springer International Publishing Switzerland; 2016. p. 181-201.

35. Tsegaye Z, Assefa F, Beyene D. Properties and application of plant growth promoting rhizobacteria. Int J Curr Trends Pharmacobiol Med Sci. 2017;2(1):30-43

36. Murthy KN, Uzma F, Chitrashree CS. Induction of systemic resistance in tomato against Ralstonia solanacearum by Pseudomonas fluorescens. Am J Plant Sci. 2014;5(12):1799-811.

37. Kannojia P, Choudhary KK, Srivastava AK, Singh AK. PGPR bioelicitors: Induced systemic resistance (ISR) and proteomic perspective on biocontrol. PGPR amelioration in sustainable agriculture: Elsevier; 2019. p. 67-84.

38. Singh D, Yadav DK, Chaudhary G, Rana VS, Sharma RK. Potential of Bacillus amyloliquefaciens for biocontrol of bacterial wilt of tomato incited by Ralstonia solanacearum. J Plant Pathol Microbiol. 2016;7(327):1-6.

39. Konappa NM, Maria M, Uzma F, Krishnamurthy S, Nayaka SC, Niranjana $\mathrm{SR}$, et al. Lactic acid bacteria mediated induction of defense enzymes to enhance the resistance in tomato against Ralstonia solanacearum causing bacterial wilt. Sci Hortic. 2016;207:183-92.

40. Wu G, Liu Y, Xu Y, Zhang G, Shen Q, Zhang R. Exploring elicitors of the beneficial rhizobacterium Bacillus amyloliquefaciens SQR9 to induce plant systemic resistance and their interactions with plant signaling pathways. Mol Plant Microbe Interact. 2018;31(5):560-7.

41. Sun D, Zhuo T, Hu X, Fan X, Zou H. Identification of a Pseudomonas putida as biocontrol agent for tomato bacterial wilt disease. Biol Cont. 2017:114:45-50.

42. Cao Y, Pi H, Chandrangsu P, Li Y, Wang Y, Zhou H, et al. Antagonism of two plant growth promoting Bacillus velezensis isolates against Ralstonia solanacearum and Fusarium oxysporum. Sci Rep. 2018;8(1):1-14.

43. Yadav BK, Sidhu AS. Dynamics of potassium and their bioavailability for plant nutrition. Potassium solubilizing microorganisms for sustainable agriculture: Springer; 2016. p. 187-201.

44. Vejan P, Abdullah R, Khadiran T, Ismail S, Nasrulhaq BA. Role of plant growth promoting rhizobacteria in agricultural sustainability - A review. Molecules. 2016;21(5):573.

45. Fenta $\mathrm{L}$, Assefa F. Isolation and characterization of phosphate solubilizing bacteria from tomato rhizosphere and their effect on growth and phosphorus uptake of the host plant under greenhouse experiment. Int J Adv Res. 2017;3:2320-5407.

46. Morsy EM, Abdel-Kawi K, Khalil M. Efficiency of Trichoderma viride and Bacillus subtilis as biocontrol agents gainst Fusarium solani on tomato plants. Egyptian J Phytopathol. 2009;37(1):47-57.

47. Dong F, Zhang X, Li Y, Wang J, Zhang S, Hu X, et al. Characterization of the endophytic antagonist PY11T-3-1 against bacterial soft rot of Pinellia ternata. Lett Appl Microbiol. 2010;50(6):611-7.

48. Ashraf M, Ahmad MSA, Öztürk M, Aksoy A. Crop improvement through different means: Challenges and prospects. Crop production for agricultural improvement: Springer; 2012. p. 1-15.

49. Schwarz D, Rouphael Y, Colla G, Venema JH. Grafting as a tool to improve tolerance of vegetables to abiotic stresses: Thermal stress, water stress and organic pollutants. Sci Hortic. 2010;127(2):162-71.

50. Nadeem SM, Naveed M, Ahmad M, Zahir ZA. Rhizosphere bacteria for crop production and improvement of stress tolerance: Mechanisms of action, applications, and future prospects. Plant microbes symbiosis: Applied facets: Springer; 2015. p. 1-36.

51. Shrivastava S, Egamberdieva D, Varma A. Plant growth-promoting rhizobacteria (PGPR) and medicinal plants: The state of the art. Plant-growthpromoting rhizobacteria (PGPR) and medicinal plants: Springer; 2015. p. $1-16$.

52. Sarbadhikary SB, Mandal NC. Field application of two plant growth promoting rhizobacteria with potent antifungal properties. Rhizosphere. 2017:3:170-5.
53. Abdallah RAB, Mokni-Tlili S, Nefzi A, Jabnoun-Khiared dine H DaamiRemadi M. Biocontrol of fusarium wilt and growth promotion of tomato plants using endophytic bacteria isolated from Nicotiana glauca organs. Biol Control. 2016;97:80-8.

54. Abdullahi S, Simon S, Babychan M. Effect of bioagents and their consortia in the management of early blight disease of potato. Int J Agri Res Innov Technol. 2016:5(3):495-8.

55. Kaymak HC. Potential of PGPR in agricultural innovations. Plant growth and health promoting bacteria: Springer; 2010. p. 45-79.

56. Choudhary DK, Varma A. Microbial-mediated induced systemic resistance in plants. New York: Springer; 2016.

57. Habib SH, Kausar H, Saud HM. Plant growth-promoting rhizobacteria enhance salinity stress tolerance in okra through ROS-scavenging enzymes. BioMed Res Int. 2016;1:1-10.

58. Belimov A, Dodd I, Safronova V, Shaposhnikov A, Azarova T, Makarova $\mathrm{N}$, et al. Rhizobacteria that produce auxins and contain 1-aminocyclopropane-1-carboxylic acid deaminase decrease amino acid concentrations in the rhizosphere and improve growth and yield of wellwatered and water-limited potato (Solanum tuberosum). Ann Appl Biol. 2015;167(1):11-25

59. Ullah U, Ashraf M, Shahzad SM, Siddiqui AR, Piracha MA, Suleman M. Growth behavior of tomato (Solanum lycopersicum L.) under drought stress in the presence of silicon and plant growth promoting rhizobacteria. Soil Environ. 2016;35(1):65-75.

60. Xun F, Xie B, Liu S, Guo C. Effect of plant growth promoting rhizobacteria and arbuscular mycorrhizal fungi (AMF) inoculation on oats in salinealkali soil contaminated by petroleum to enhance phytoremediation. Environ Sci Poll Res. 2015;22:598-608.

61. Tariq M, Noman M, Ahmed T, Hameed A, Manzoor N, Zafar M. Antagonistic features displayed by plant growth promoting rhizobacteria (PGPR): A review. J Plant Sci Phytopathol. 2017;1:38-43.

62. Jadhav H, Sayyed R. Hydrolytic enzymes of rhizospheric microbes in crop protection. MOJ Cell Sci Rep. 2016;3(5):1-2.

63. Yandigeri MS, Malviya N, Solanki MK, Shrivastava P, Sivakumar G. Chitinolytic Streptomyces vinaceusdrappus S5MW2 isolated from Chilika lake, India enhances plant growth and biocontrol efficacy through chitin supplementation against Rhizoctonia solani. World J Microbiol Biotechnol. 2015:31(8):1217-25.

64. Radhakrishnan R, Hashem A, Abd-Allah EF. Bacillus: A biological tool for crop improvement through bio-molecular changes in adverse environments. Front Physiol. 2017:8:1-14.

65. Xu S, Kim BS. Evaluation of Paenibacillus polymyxa strain SC09-21 for biocontrol of phytophthora blight and growth stimulation in pepper plants. Trop Plant Pathol. 2016;41(3):162-8.

66. Nega A. Review on concepts in biological control of plant pathogens. J Biol Agri Healthcare. 2014;4(27):33-54.

67. Guchi E. Disease management practice on potato (Solanum tuberosum L.) in Ethiopia. World J Agri Res. 2015;3(1):34-42.

68. Nguyen M, Ranamukhaarachchi S. Soil-borne antagonists for biological control of bacterial wilt disease caused by Ralstonia solanacearum in tomato and pepper. J Plant Pathol. 2010;92:395-405.

69. Kinyua Z, Smith J, Lung'aho C, Olanya M, Priou S. On farm successes and challenges of producing bacterial wilt-free tubers in seed plots in Kenya. Afr Crop Sci J. 2001;9(1):279-85.

70. Zegeye ED, Santhanam A, Gorfu D, Tessera M, Kassa B. Biocontrol activity of Trichoderma viride and Pseudomonas fluorescens against Phytophthora infestans under greenhouse conditions. J Agri Technol. 2011;7(6):1589-602.

71. Youssef NA, Hassan GM. Bioinsecticide activity of Bacillus thuringiensis isolates on tomato borer, Tuta absoluta (Meyrick) and their molecular identification. Afri J Biotechnol. 2013;12(23):3699-709.

72. Terefe M, Tefera T, Sakhuja P. Effect of a formulation of Bacillus firmus on root-knot nematode Meloidogyne incognita infestation and the growth of tomato plants in the greenhouse and nursery. J Invert Pathol. 2009; 100(2):94-9.

73. Gangwar RK. Role of biological control agents in integrated pest management approaches. Acta Sci Agri. 2017;1:9-11.

74. Ramamoorthy $V$, Raguchander T, Samiyappan R. Enhancing resistance of tomato and hot pepper to pythium diseases by seed treatment with fluorescent pseudomonads. Eur J Plant Pathol. 2002;108(5):429-41. 
75. Ali-Rezaei A, Talaei-Hassanloui R. The use of Bacillus thuringiensis-based products in biocontrol of tomato leaf miner, Tuta absoluta (Lepidoptera Lelechiidae). Int J Agri Innov Res. 2016;4(4):814-7.

76. Jamshidnia A, Abdoli S, Farrokhi S, Sadeghi R. Efficiency of spinosad, Bacillus thuringiensis and Trichogramma brassicae against the tomato leafminer in greenhouse. Biocontrol. 2018;63(5):619-27.

77. Tadele S, Emana G. Entomopathogenic effect of Beauveria bassiana (bals.) and Metarrhizium anisopliae (Metschn) on Tuta absoluta (Meyrick) (Lepidoptera: Gelechiidae) larvae under laboratory and glasshouse conditions in Ethiopia. J Plant Pathol Microbiol. 2017;8:1-4

78. Tian B, Yang J, Zhang KQ. Bacteria used in the biological control of plantparasitic nematodes: populations, mechanisms of action, and future prospects. FEMS Microbiol Ecol. 2007;61(2):197-213.
79. Al-Shalaby ME, Sedik M. Biocontrol activity of some bacterial isolates against Meloidogyne incognita. Egypt J Biol Pest Control. 2008;18(1):119-25.

80. Cetintas R, Kusek M, Fateh SA. Effect of some plant growth-promoting rhizobacteria strains on root-knot nematode, Meloidogyne incognita, on tomatoes. Egyptian J Biol Pest Cont. 2018;28(1):1-5.

\section{Publisher's Note}

Springer Nature remains neutral with regard to jurisdictional claims in published maps and institutional affiliations.

\section{Submit your manuscript to a SpringerOpen ${ }^{\circ}$ journal and benefit from:}

- Convenient online submission

- Rigorous peer review

- Open access: articles freely available online

- High visibility within the field

- Retaining the copyright to your article

Submit your next manuscript at $\boldsymbol{\nabla}$ springeropen.com 